\title{
Neutralisation treatment of AMD at affordable cost
}

\author{
JP Maree*, M Mujuru, V Bologo, N Daniels and D Mpholoane \\ Department of Water, Environment and Earth Sciences, Tshwane University of Technology, Private Bag X650, Pretoria, 0001
}

\section{ABSTRACT}

Acid mine drainage (AMD) has for many years been a major environmental challenge associated with the mining industry, especially in the Eastern, Central and Western mining basins of Gauteng. The aims of this article are to: (i) demonstrate the suitability of the sequencing batch reactor (SBR) system for both neutralisation of free acid and removal of iron(II), often the main component in AMD, using limestone, the cheapest alkali, followed by lime treatment for removal of heavy metals, and partial sulphate removal through gypsum crystallisation; (ii) compare the alkali cost of the alternative SBR system where limestone and lime are used for treatment, with conventional lime treatment, and (iii) present the capital cost of the SBR system.

The conclusions of this study are that: (i) precipitated calcium carbonate can be used for complete removal of iron(II) in an SBR system within 90 min reaction time; (ii) lime can be used for complete removal of heavy metals after pre-treatment with precipitated calcium carbonate; (iii) the alkali cost for treatment of AMD from the Western Basin will amount to $\mathrm{R} 2.80 / \mathrm{m}^{3}$ in the case of limestone/lime treatment compared to $\mathrm{R} 5.83 / \mathrm{m}^{3}$ if only lime is used; (iv) the alkali cost for treatment of $85 \mathrm{MP} / \mathrm{d}$ acid mine water from both the Western and Central Basins will amount to R60 m./a in the case of limestone/lime treatment compared to R136.9 m./a if only lime is used; and (v) the capital cost for the SBR system amounts to R3.5 m. per $\mathrm{Me} / \mathrm{d}$.

Keywords: Acid mine drainage, sequencing batch reactor, neutralisation, limestone

\section{INTRODUCTION}

Acid mine drainage (AMD) has for many years been a major environmental challenge associated with the mining industry, especially in the Western, Central and Eastern mining basins of Gauteng. The Western Basin AMD decants uncontrolled at a flow rate of $10-60 \mathrm{M} / \mathrm{d}$. This water has a $\mathrm{pH}$ of 2.8 and contains $\mathrm{Fe}(\mathrm{II})$, free acid, manganese and uranium, is detrimental to the environment and the health of humans and animals, is unsuitable for irrigation and threatens the stability of the dolomitic rock at the Cradle of Humankind World Heritage Site. The immediate construction of a neutralisation plant is required for removal of free acid, metals and uranium, and for partial sulphate removal. Similar situations exist in the Central Basin near Boksburg and in the Eastern Basin near Springs. In the Central Basin the water was at a depth of $540 \mathrm{~m}$ below the decant level at the time of writing, and rising at an average daily rate of $0.7 \mathrm{~m}$. It is anticipated that decanting of acid mine water, at an expected rate of $60 \mathrm{Ml} / \mathrm{d}$, may start in 2013/14. The quality of this water is also acidic and saline, similar to the AMD decanting from the Western Basin.

Mine water typically contains 4 main components: free acid, iron(II), a number of heavy metals and salts (Maree, 2012). The formation of AMD can be attributed to the convergence of the following events:

- dissolution of limestone/dolomite up to its solubility level in natural, ingress water

- pyrite oxidation by bacterial action as a result of oxygenrich ingress water running through broken pyritecontaining rock within the mine environment and producing acidity, $\mathrm{Fe}(\mathrm{II})$, sulphates and other salts

\footnotetext{
To whom all correspondence should be addressed.

082465 3547; e-mail: mareej@tut.ac.za

Received 11 June 2012; accepted in revised form 27 March 2013.
}

- partial neutralisation of free acid due to natural alkalinity contained in the mined and broken rock media

- reciprocating contact of pyrites-rich rock with water and oxygen when the water level fluctuates as a result of water being pumped out at a constant rate, whilst the water recharge varies with seasonal rainfall.

The Expert Team of the Inter-Ministerial Committee on Acid Mine Drainage investigated the matter in 2010 and recommended specific actions to further manage and control the AMD associated with the Witwatersrand mining boom (Expert Team of the Inter-Ministerial Committee under the Coordination of the Council for Geoscience, 2011), as follows:

- installation of pumping facilities in each of the mining basins to maintain the water level below the Environmental Critical Level (ECL)

- construction of measures to reduce the water ingress and recharge to the underground mine workings

- treatment of the excess mine water

- comprehensive monitoring

- investigation of and addressing other sources of AMD

- investigation of and research work to find long-term sustainable solutions

- investigation of the feasibility of implementing an environmental levy on operating mines to fund environmental rehabilitation

- ongoing assessment and research work.

An important consideration related to AMD is the management of sludge produced during treatment of acid mine water. Zinck (2006) has described various ways to deal with such sludge. Ruto et al. (2011) described the GypSLiM process that can be used for processing gypsum into sulphur and $\mathrm{CaCO}_{3}$. Chemical desalination processes, such as CSIR ABC, TUT $\mathrm{MBO}$ and Mintek Ettringite processes, can produce drinking water from AMD in a cost-effective way without a resulting 
sludge disposal problem, as feed chemicals and saleable byproducts are recovered from the produced sludge.

The Department of Water Affairs (DWA) has appointed the Trans-Caledon Tunnel Authority (TCTA) to implement the selected recommendations of the Inter-Ministerial Committee on Acid Mine Water (Creamer, 2012). In June 2011, after a tender process, BKS and Golder Associates were appointed to develop a short-term plan to address the immediate concerns of the AMD problem. An urgent task was to neutralise the water decanting in the Western, Central and Eastern Basins (Creamer, 2012). Owing to the huge threat posed by AMD, it was decided by TCTA to employ proven technology that uses limestone treatment for neutralisation of free acid, followed by additional lime treatment for removal of iron(II) and other heavy metals (Van Niekerk, 2011). This approach has been applied widely for treatment of AMD (Aubé, 2004). This treatment process (referred to as the 'high density sludge (HDS)' process) consists of a $\mathrm{pH}$ correction/sludge conditioning stage, a neutralisation/ aeration stage, and a solid/liquid separation stage (Osuchowski, 1992). A due diligence study of the Witwatersrand mining basins estimated the capital cost of AMD neutralisation plants for the three basins at R924 $\mathrm{m}$. As only R255 m. was approved for this project by Cabinet (Creamer, 2012), ways of making up the shortfall of R669 m. need to be identified, or, alternatively, options for reducing this high capital cost need to be investigated and applied.

The following options can be considered to reduce the funding gap in the establishment of AMD neutralisation plants:

\section{Raise the environmental critical level (ECL) to reduce pumping costs}

Two views can be considered on whether mine water needs to be pumped out.

- In View 1 mine water can be pumped out to maintain the water level below a selected environmental critical level (ECL). In this way water is not permitted to rise above the level where it makes contact with and dissolves limestone/ dolomite. This practice also offers benefits such as preventing groundwater pollution, preventing damage to building foundations and providing flow-equalisation storage in sub-surface mining voids to allow a constant feed rate to the treatment plant. A negative outcome of this approach is that as natural ingress water follows the same channels on its way to the underground mine water body it will dissolve the dolomite/limestone rock and can result in sinkhole formation, i.e., when pockets of limestone-containing rock get dissolved over time in water that is under-saturated with respect to $\mathrm{CaCO}_{3}$.

- In View 2 mine water is allowed to decant naturally. This view is based on the fact that no oxidation of pyrites takes place when the rock is submerged and oxygen is excluded. This practice will also reduce limestone dissolution by ingress water. If water is allowed to decant, surface storage facilities (e.g. ponds) need to be constructed to allow constant feed to the water treatment plant. This option would result in less acidity and less Fe(II) in the AMD than the pumping option. The negative impacts of having AMD at shallower depths will need to be managed.

It can be argued that both views have a place, depending on the application. In order to choose between Views $\mathbf{1}$ and $\mathbf{2}$, it was necessary to quantify the impact of the two views on the different situations prevailing in the Western, Central and
Eastern Basins. Maree (2012) showed that the capital cost for AMD pump stations in the three basins to maintain the recommended ECL levels of $150 \mathrm{~m}$ (below decant) for the Western Basin, $200 \mathrm{~m}$ (below decant) for the Central Basins and 400 $\mathrm{m}$ (below decant) for the Eastern Basin will amount to R211.4 $\mathrm{m}$. The electrical power cost was estimated at R $57.8 \mathrm{~m}$./a. By raising the ECL to a higher level of $30 \mathrm{~m}$ (below decant), the capital cost will be reduced to $\mathrm{R} 20.5 \mathrm{~m}$. and the power cost to R5.6 m./a. The cost to compensate for pollution of groundwater by providing piped municipal water (from Rand Water) to local groundwater users will be much less than the cost of pumping high volumes of water against a high pressure head. These figures need to be confirmed in order to ascertain where Views $\mathbf{1}$ and $\mathbf{2}$ are able to and need to be applied.

\section{Apply decentralised rather than a centralised neutralisation treatment}

The combined cost of AMD pipelines and pumping of water are significantly higher than that of AMD treatment plants. The capital cost of a pump station and pipeline that can transport $25 \mathrm{Ml} / \mathrm{d}$ water over a distance of $20 \mathrm{~km}$ is estimated at $\mathrm{R} 60 \mathrm{~m}$. and the electricity cost at R5 m./a. In the medium term, this is more costly than an AMD treatment plant, costing an estimated R70 m.

\section{Use South African developed technologies}

New technologies could be used for neutralisation of the following waters:

- The highly-polluted AMD of the Western and Central Basins can be treated with limestone for neutralisation of free acid and iron(II) removal, followed by lime treatment for removal of the other heavy metals (present investigation).

- The less-polluted AMD from the Eastern Basin, which has a low acidity, is treatable with only air/oxygen for iron(II) oxidation and precipitation. Due to its high alkali content, a technology could be developed that will eliminate the need for dosing of any alkali.

- Use South African developed technologies for desalination of neutralised water such as the CSIR ABC, TUT MBO or Mintek Ettringite processes.

AMD can be neutralised with limestone and/or lime. Chemical costs would be the lowest if free acid $\left(\mathrm{H}_{2} \mathrm{SO}_{4}, \mathrm{Fe}(\mathrm{III})\right.$ and $\mathrm{Al}(\mathrm{III})$ ) and $\mathrm{Fe}(\mathrm{II})$ ) are neutralised/removed with limestone and lime used only for removal of manganese and other heavy metals, such as copper and nickel. Free acid can easily be removed with limestone, but $\mathrm{Fe}(\mathrm{II})$ removal requires special conditions. As Fe(II) is the dominant dissolved species in Witwatersrand $\mathrm{AMD}$, it is important that the selected process configuration effectively removes Fe(II), in the first limestone stage. The sequencing batch reactor (SBR) is an improvement on the existing limestone neutralisation technology currently employed at several mines, especially when the focus is on Fe(II)-oxidation. In this system, limestone in the form of powdered calcium carbonate is used for neutralisation to raise the $\mathrm{pH}$ sufficiently for $\mathrm{Fe}(\mathrm{II})$-oxidation to take place.

An investigation was undertaken by the Tshwane University of Technology's Department of Water, Environmental and Earth Sciences in collaboration with Anglo Coal and Rand Uranium to evaluate the treatment of AMD using the limestone/lime process within a SBR reactor. The 


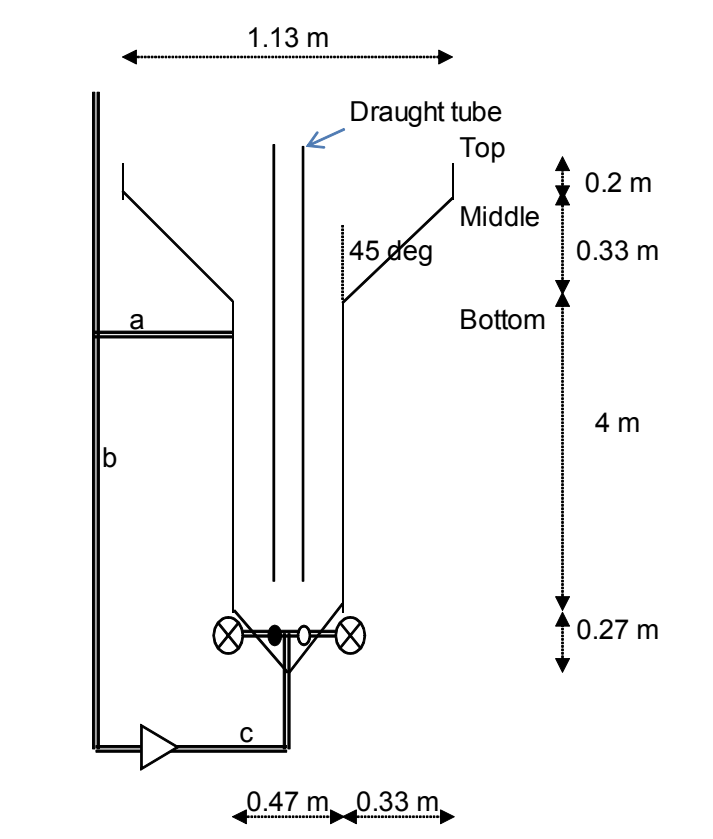

Dia of pipes on delivery side of recycle pump (a, b) $=75 \mathrm{~mm}$ Dia of pipe on delivery side of recycle pump (c) $=38 \mathrm{~mm}$

Figure 1

Dimensions of column reactor

aims of this investigation were to achieve the following:

- Demonstrate technical feasibility of the SBR at laboratory and pilot scale

- Compare the capital and running costs of a conventional neutralisation process configuration with a process incorporating the new SBR process.

\section{MATERIALS AND METHODS}

The following AMDs were used: toe seep leachate from a coal discard dump containing $6000 \mathrm{mg} / \ell \mathrm{Fe}(\mathrm{II}), 18000 \mathrm{mg} / \ell$ acidity and $25000 \mathrm{mg} / \ell$ sulphate; decant water from the Western Basin of Witwatersrand. Precipitated calcium carbonate $(100 \%<300$ $\mu \mathrm{m}$ and $80 \%<75 \mu \mathrm{m}$ ), a by-product from the paper industry, was used for neutralisation. Lime (commercial grade) was used to raise the $\mathrm{pH}$ to 9 for removal of manganese.

Batch studies were conducted in $1.0 \mathrm{\ell}$ beakers at atmospheric pressure to determine the rate of iron oxidation and neutralisation. Batch studies were also carried out at pilot scale in a column reactor (Fig. 1); a completely-mixed/clarifier process (Fig. 2) provided with a mechanical mixer for mixing and aeration; and a completely-mixed/clarifier process (Fig. 2) provided with a fine bubble diffuser for mixing and aeration. Each batch test was started by mixing a portion of the sludge from the previous batch with untreated water and a $10 \%$ excess of $\mathrm{CaCO}_{3}$, to ensure complete iron oxidation and precipitation of the $\mathrm{Fe}(\mathrm{III})$ as $\mathrm{Fe}(\mathrm{OH})_{3}$. The reactor contents were aerated continuously. Samples were taken regularly, filtered and analysed for iron(II), dissolved oxygen, acidity, sulphate and pH. Aeration was stopped when the iron was completely oxidised, whereafter solids were allowed to settle, clear water was decanted and then replaced with a fresh AMD. Aeration was restarted and the procedure described above repeated.

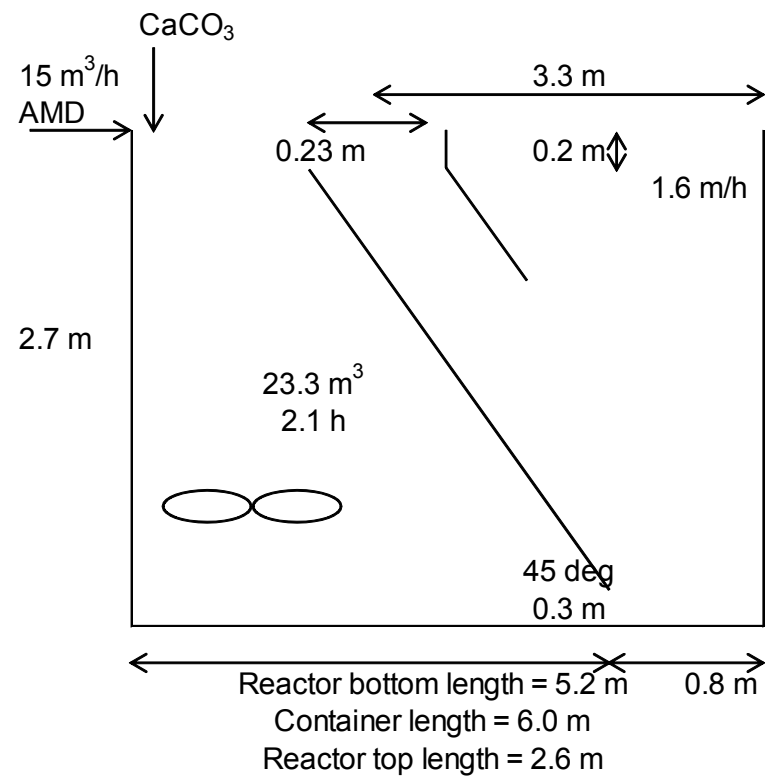

Figure 2

Dimensions of completely-mixed reactor/clarifier

Samples were collected regularly and filtered (Whatman No 1 glass fibre filter). Sulphate, acidity, and $\mathrm{pH}$ determinations were carried out manually according to procedures described in APHA et al.(1985) and Fe(II) determinations was carried out as described in Vogel (1989). Calcium was analysed using atomic absorption spectrophotometry. Acidity was determined by titrating the solution to $\mathrm{pH} 8.3$ using $0.1 \mathrm{M} \mathrm{NaOH}$.

\section{RESULTS AND DISCUSSION}

\section{Iron(II)-oxidation}

Figure 3 shows the behaviour of $\mathrm{pH}, \mathrm{Fe}(\mathrm{II})$ and acidity with time when acid water from a coal discard facility was neutralised with calcium carbonate in the presence of sparged air. It was noted that $120 \mathrm{~min}$ was needed for raising the $\mathrm{pH}$ from 2.7 to 7.0 and for complete removal of Fe(II) and acidity. The $\mathrm{pH}$ behaviour went through 3 stages. During Stage 1 the $\mathrm{pH}$ increased sharply from 2.7 to 6.0 when free acid was neutralised. During Stage 2 the $\mathrm{pH}$ remained constant at 6 while iron(II) was being oxidised to iron(III). During Stage 3 the $\mathrm{pH}$ increased from 6.0 to 7.0 when the final traces of iron(II) were oxidised and when $\mathrm{CO}_{2}$ was stripped from solution. In the existing coal discard seepage treatment plant (a continuous completely mixed reactor), iron(II) is only partially removed due to the higher flow-rate and higher iron(II) concentration compared to the original plant basis of design. The required neutralisation time is dependent on the rate of iron(II) oxidation and process conditions that supply sufficient air/oxygen would accelerate the process. Changing from continuous to batch mode could shorten the required retention time from $4 \mathrm{~h}$ down to $2 \mathrm{~h}$. Table 1 shows the chemical composition of the AMD before and after treatment with calcium carbonate and lime. During calcium carbonate treatment, iron(II) and acidity were completely removed and the $\mathrm{pH}$ was raised to 7 . During subsequent lime treatment, manganese was completely removed. Sulphate concentration 


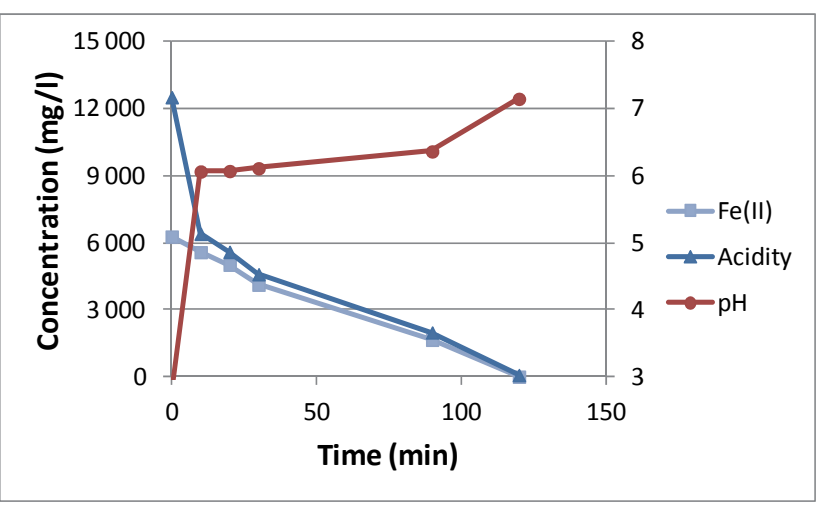

Figure 3

Behaviour of various parameters when coal discard seepage was neutralised with limestone

was lowered from $17000 \mathrm{mg} / \ell$ in the feed AMD to $3500 \mathrm{mg} / \ell$ after limestone treatment and to $2900 \mathrm{mg} / \ell$ after lime treatment. The total dissolved solids content was lowered from $25000 \mathrm{mg} / \ell$ in the coal discard seepage to $4900 \mathrm{mg} / \ell$ after calcium carbonate treatment, and to $4000 \mathrm{mg} / \ell$ after lime treatment.

Figure 4 shows a comparison of the rates of iron(II) removal at pilot scale in the following reactor configurations: (i) completely-mixed reactor with a fine bubble diffuser for aeration and mixing; (ii) completely-mixed reactor with a mechanical mixer for aeration and mixing, and (iii) column reactor with a draft tube for mixing, with bubble aeration. Iron(II) was successfully removed in all three systems but fastest in the column reactor, followed by the mechanical mixing system, and then the fine bubble diffuser system. The rate of Fe(II)-oxidation is influenced by iron(II) concentration, oxygen concentration, $\mathrm{pH}$, suspended solids content and mixing intensity. Stumm and Lee (1961) determined the following relationship between iron oxidation rate and $\mathrm{pH}$ in the absence of microorganisms for clear solutions (Eq. (1)):

$$
-d\left[\mathrm{Fe}^{2+}\right] / d t=k \cdot\left[\mathrm{Fe}^{2+}\right]\left[\mathrm{OH}^{-}\right]^{2} P_{\mathrm{O} 2}
$$

where:

$$
\begin{aligned}
& -d\left[\mathrm{Fe}^{2+}\right] / d t=\text { rate of iron oxidation } \\
& k=\text { reaction rate constant } \\
& {\left[\mathrm{Fe}^{2+}\right]=\mathrm{Fe}(\mathrm{II}) \text { concentration }(\mathrm{mol} / \ell)} \\
& {\left[\mathrm{OH}^{-}\right]=\text {hydroxide concentration }(\mathrm{mol} / \ell)} \\
& P_{\mathrm{O} 2}=\text { partial pressure of oxygen }(\mathrm{Pa})
\end{aligned}
$$

Maree et al. (2004) demonstrated that the rate of iron oxidation was also catalysed by suspended solids when $\mathrm{CaCO}_{3}$ is used for neutralisation. In the $\mathrm{pH}$ range $5-7$, which is of importance for $\mathrm{CaCO}_{3}$ neutralisation, the iron oxidation rate was assumed to have the following functional form:

$$
-d\left[\mathrm{Fe}^{2+}\right] / d t=\mathrm{k} \cdot\left[\mathrm{Fe}^{2+}\right]^{\mathrm{n} \cdot} \cdot\left[\mathrm{O}_{2}\right]^{\mathrm{n} 2} \cdot[\mathrm{OH}-]^{\mathrm{n} 3} \cdot[\mathrm{SS}]^{\mathrm{n} 4} \cdot \mathrm{M}^{\mathrm{n} 5}
$$

\begin{tabular}{|c|c|c|c|c|c|c|c|c|}
\hline \multicolumn{9}{|c|}{$\begin{array}{c}\text { TABLE } 1 \\
\text { Chemical composition of feed and treated water and cost of alkali }\end{array}$} \\
\hline \multirow[t]{4}{*}{ Parameter } & \multicolumn{4}{|c|}{ Toe Seep } & \multicolumn{4}{|c|}{ Western Basin } \\
\hline & Feed & Treated & & & Feed & Treated & & \\
\hline & & \multicolumn{2}{|c|}{$\begin{array}{c}\text { Option } 1 \\
\left(\mathrm{CaCO}_{3} \text { for free acid }\right. \\
\text { and } \mathrm{Fe}(\mathrm{II}) ; \text { lime for } \\
\text { metals) }\end{array}$} & $\begin{array}{l}\text { Option } \\
2 \text { (Only } \\
\text { lime) }\end{array}$ & & \multicolumn{2}{|c|}{$\begin{array}{c}\text { Option } 1 \\
\text { (CaCO for free acid } \\
\text { and Fe(II); Lime for } \\
\text { metals) }\end{array}$} & $\begin{array}{c}\text { Option } \\
2 \text { (only } \\
\text { lime) }\end{array}$ \\
\hline & & $\mathrm{CaCO}_{3}$ & Lime & Lime & & $\mathrm{CaCO}_{3}$ & Lime & Lime \\
\hline Flow (Me/d) & & & 1.75 & 1.75 & & & 25 & 25 \\
\hline Dosage $(g / \ell)$ & & 2.00 & 0.30 & 12.53 & & 3.94 & 0.52 & 2.92 \\
\hline Price $(\mathrm{R} / \mathrm{t})$ & & 449 & 2000 & 2000 & & 449 & 2000 & 2000 \\
\hline $\operatorname{Cost}\left(\mathrm{R} / \mathrm{m}^{3}\right)$ & & 9.02 & 0.59 & 25.07 & & 1.77 & 1.03 & 5.83 \\
\hline $\operatorname{Cost}\left(\mathrm{R} / \mathrm{m}^{3}\right)$ & & 9.61 & & 25.07 & & 2.80 & & 5.83 \\
\hline Cost (R million/year) & & 0.51 & & 1.33 & & 25.55 & & 53.23 \\
\hline Cost ratio & & 0.38 & & 1.00 & & 0.48 & & 1.00 \\
\hline $\mathrm{pH}$ & 3.4 & 6.6 & 9.2 & 9.2 & 2.9 & 6.6 & 9.2 & 9.2 \\
\hline Alkalinity $\left(\mathrm{mg} / \ell\right.$ as $\left.\mathrm{CaCO}_{3}\right)$ & 0 & 100 & 200 & 200 & & 100 & 200 & 200 \\
\hline Sulphate $\left(\mathrm{mg} / \ell\right.$ as $\left.\mathrm{SO}_{4}\right)$ & 16200 & 3023 & 2826 & 2826 & 4800 & 2701 & 2285 & 2285 \\
\hline Chloride $(\mathrm{mg} / \ell$ as $\mathrm{Cl})$ & 6 & 6 & 6 & 6 & 37 & 37 & 37 & 37 \\
\hline Sodium $(\mathrm{mg} / \mathrm{\ell}$ as $\mathrm{Na})$ & 80 & 80 & 80 & 80 & 50 & 50 & 50 & 50 \\
\hline Magnesium (mg/l as Mg) & 268 & 268 & 268 & 268 & 147 & 147 & 147 & 147 \\
\hline Free acidity $\left(\mathrm{mg} / \ell\right.$ as $\left.\mathrm{CaCO}_{3}\right)$ & 101 & 0 & 0 & 0 & 979 & 0 & 0 & 0 \\
\hline Aluminium $(\mathrm{mg} / \ell$ as $\mathrm{Al})$ & 375 & 0.0 & 0.0 & 0.0 & 6 & 0.0 & 0.0 & 0.0 \\
\hline $\operatorname{Iron}(\mathrm{II})(\mathrm{mg} / \ell$ as $\mathrm{Fe})$ & 5800 & 10.0 & 0.0 & 0.0 & 625 & 10.0 & 0.0 & 0.0 \\
\hline $\operatorname{Iron}(\mathrm{III})(\mathrm{mg} / \ell$ as $\mathrm{Fe})$ & 0 & 0.0 & 0.0 & 0.0 & 100 & 0.0 & 0.0 & 0.0 \\
\hline Manganese (mg/ $\ell$ as $M n)$ & 103 & 103.0 & 0.0 & 0.0 & 228 & 228.0 & 0.0 & 0.0 \\
\hline Calcium calc (mg/ $\ell$ as $\mathrm{Ca})$ & 1135 & 705 & 745 & 745 & 602 & 720 & 760 & 760 \\
\hline TDS (calc) (mg/l) & 17804 & 4255 & 4055 & 4055 & 5995 & 3954 & 3410 & 3410 \\
\hline
\end{tabular}

where:

$-d\left[\mathrm{Fe}^{2+}\right] / d t$ rate of iron oxidation

$k=$ reaction rate constant

$\left[\mathrm{Fe}^{2+}\right]=\mathrm{Fe}^{2+}$ concentration $(\mathrm{mol} / \mathrm{l})$

$\left[\mathrm{OH}^{-}\right]=$hydroxide concentration $(\mathrm{mol} / \ell)$

$\left[\mathrm{O}_{2}\right]=$ oxygen concentration $(\mathrm{mol} / \mathrm{\ell})$ 


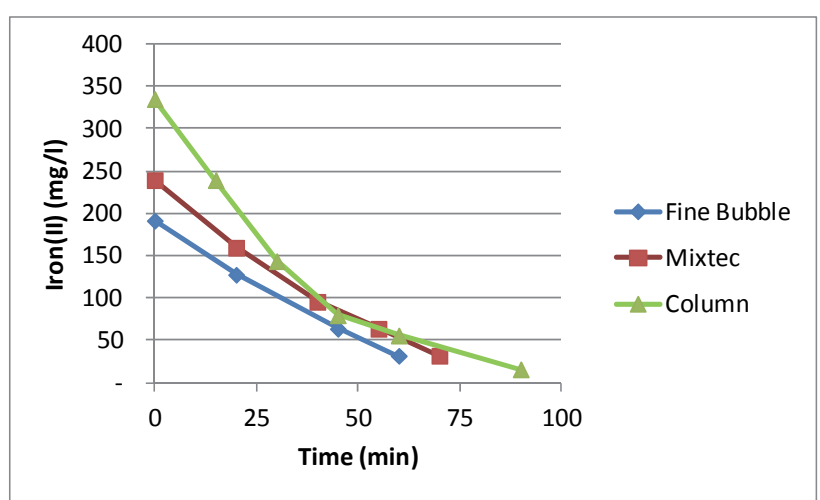

Figure 4

Comparison between Fe(II)-oxidation rates for fine bubble diffuser, Mixtec mixer and column reactor

[SS] = suspended solid concentration

$\mathrm{M}=$ mixing intensity $(\mathrm{r} / \mathrm{min})$

Figure 5 shows the specific iron(II)-oxidation rates for the three systems. It was noted that the highest values were measured for the column reactor ( 5 to $13 \mathrm{mg} \mathrm{Fe} /(\ell \cdot \mathrm{min}))$ followed by the mechanical mixing system $(3-5 \mathrm{mg} \mathrm{Fe} /(\ell \cdot \mathrm{min}))$ and the fine bubble diffuser system (1 to $4 \mathrm{mg} \mathrm{Fe} /(\ell \cdot \mathrm{min})$ ).

From the above information, the higher specific rate of $\mathrm{Fe}(\mathrm{II})$-oxidation in the case of the column reactor was ascribed to the greater depth of $4 \mathrm{~m}$, compared to the $2 \mathrm{~m}$ depth in the case of the completely-mixed reactor. Due to the greater depth it is assumed that more oxygen was present in solution. The slightly higher rate in the case of the mechanical mix reactor can be ascribed to improved mixing conditions.

From the experimental findings above it was concluded that the full-scale plant design should meet the following criteria to ensure iron(II) removal under optimum conditions:

- Maintain a high sludge concentration

- Maintain a higher oxygen concentration in solution

- Ensure good mixing conditions

\section{Water quality and alkali cost}

Significant financial savings can be realised if the conventional process flow diagram is revised to include the following new developments: (i) use limestone not only for neutralisation of free acid $\left(\mathrm{H}_{2} \mathrm{SO}_{4}, \mathrm{Fe}^{3+}\right.$ and $\left.\mathrm{Al}^{3+}\right)$, but also for removal of iron(II); and (ii) use the SBR for limestone/lime treatment, as it provides the essential conditions needed for Fe(II) oxidation with limestone. Table 1 shows the chemical composition of the feed AMD before and after treatment with limestone and lime. It was noted that:

- The alkali cost for Western Basin water using the SBR, where limestone is used for removal of free acid and iron(II), and lime solely for removal of heavy metals,

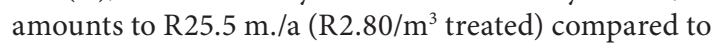
$\mathrm{R} 53.2 \mathrm{~m} . / \mathrm{a}$ (R5.83/ $\mathrm{m}^{3}$ treated) when lime is employed for both stages.

- The corresponding cost figures for both Western and Central Basins together amount to R60.3 m./a (R2.80/ $\mathrm{m}^{3}$ treated) for the SBR process compared to R $136.9 \mathrm{~m}$./a (R5.83/ $\mathrm{m}^{3}$ treated) using lime for both stages.

- For coal discard seepage the corresponding cost figures amount to R511 000/a (R9.61/. $\left.\mathrm{m}^{3}\right)$ compared to R1.3 m./a $\left(\mathrm{R} 25.07 / \mathrm{m}^{3}\right)$.

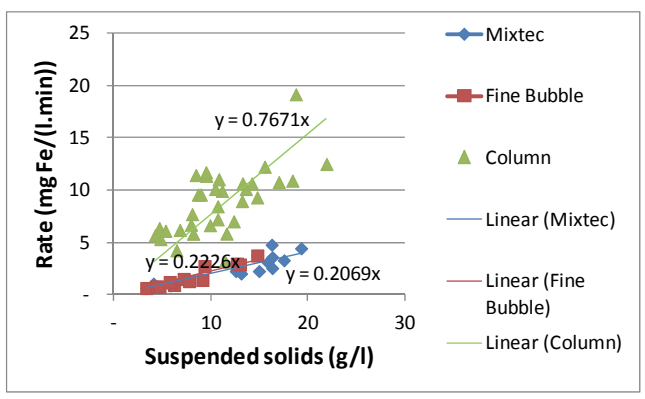

\begin{tabular}{|l|l|l|}
\hline Reactor & Suspended solids $(\mathrm{g} / \ell)$ & Rate $(\mathrm{mg} \mathrm{Fe} /(\ell \cdot \mathrm{min}))$ \\
\hline Fine bubble & 13.0 & 2.9 \\
\hline Mechanical mixer & 16.4 & 3.6 \\
\hline Column & 4.7 & 6.4 \\
\hline
\end{tabular}

\section{Figure 5}

Relationship between iron(II) oxidation rate and suspended solids content for aeration with a column reactor, mechanical mixer and with fine bubble diffusion

\section{Process diagram}

Figure 6 shows a schematic configuration for the SBR system. The plant design is based on the following principles:

- Sequencing batch reactor. The SBR is a prefabricated steel tank, lined to protect the metal from corrosion. It is equipped with a compressor and fine bubble diffuser for aeration and a draught tube to mix the slurry contained in the reactor. Mine water, sludge and limestone slurry is first pumped into the SBR to allow acid neutralisation, iron(II)oxidation and some gypsum crystallisation. Upon completion of iron(II)-oxidation, lime is dosed to precipitate metals and to allow further gypsum crystallisation. This approach affords a lower alkali cost as limestone $\left(\mathrm{CaCO}_{3}\right)$ is used for neutralisation of free acid $\left(\mathrm{H}_{2} \mathrm{SO}_{4}\right)$ and, with the aid of aeration, removal of iron(II) as iron(III), and removal of aluminium(III), which form the main dissolved cations of Witwatersrand AMD. Lime is used only for removal of metals such as manganese and magnesium. It also results in reduced plant capital cost owing to faster reaction rates and fewer unit operations. Reaction rates are related to the concentrations of the various reactants; the higher the concentrations, the faster the reaction rates. A further advantage is that AMD remains in one reactor, while being treated first with limestone and then with lime. Other benefits of the SBR system are direct control of effluent quality and partial desalination to sulphate levels lower than 2000 $\mathrm{mg} / \ell$, through gypsum crystallisation.

- Clarifier. Upon completion of the neutralisation, oxidation and crystallisation reactions, the batch contents of the SBR are drained into one of the clarifiers. This allows maximum throughput in the more sophisticated SBR. Two clarifiers are provided for each SBR reactor to allow sufficient settling time for slurry with a high solids content.

- Limestone handling and dosing system. Limestone (precipitated calcium carbonate, or milled limestone, both with a moisture content of 25\%) is stored in a limestone V-shaped storage and dosing facility. A water jet is used to slurry the limestone to a solids content of $20 \%$ in the slurry dosed into the reactor.

- Simple chemical storage facility. Limestone is available from the paper industry (SAPPI); an alternative source will be mined limestone that is milled on-site or at the mine 


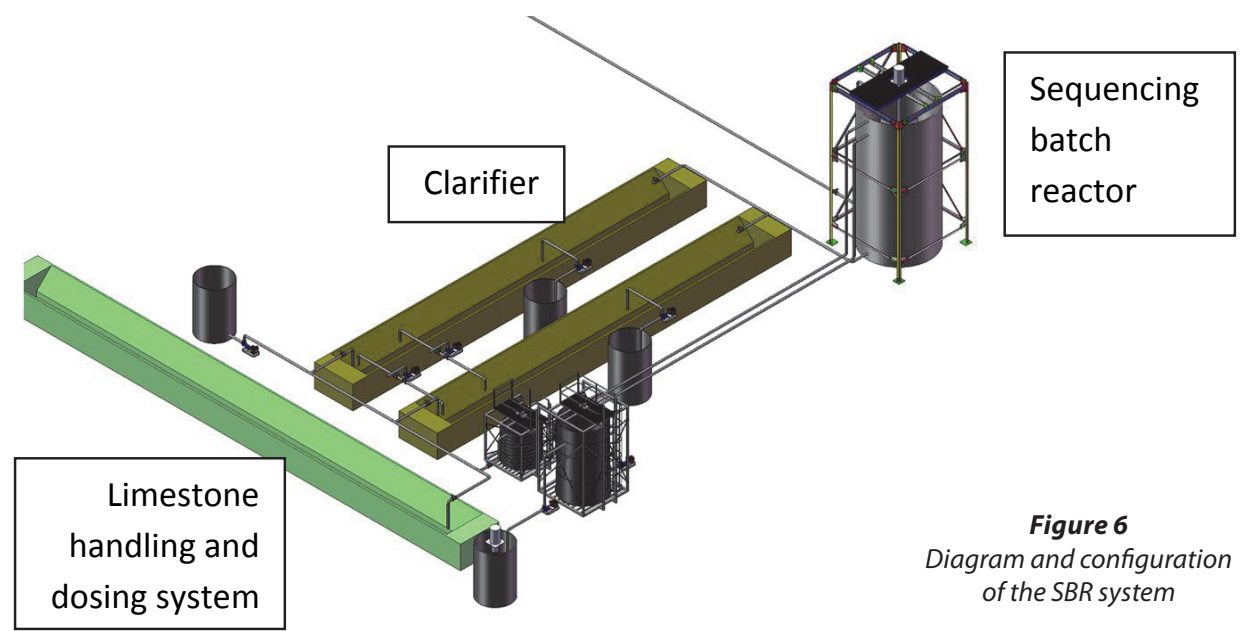

in a wet mill. This product is available at the same cost as that of the precipitated calcium carbonate from the paper industry. Wet milling offers the benefit that the raw material can be transported in tipper trucks and will not need to be stored in silos. The same limestone handling and dosing systems that are currently used by the mining groups can be employed.

The estimated capital cost of this SBR treatment system amounts to R3.5 m. per Ml/d treatment capacity.

\section{CONCLUSIONS}

Two conclusions can be drawn from this work:

- Limestone (calcium carbonate) can be used for complete removal of iron(II) in an SBR system within 90 min reaction time. Subsequently, lime can be used for complete removal of metals. The alkali cost for treatment of AMD from the Western Basin would amount to $\mathrm{R} 2.80 / \mathrm{m}^{3}$ treated in the case of limestone/lime treatment, compared to $\mathrm{R} 5.83 / \mathrm{m}^{3}$ treated if lime is used for both stages.

- The estimated capital cost for the SBR process amounts to R3.5 m. per Me/d.

\section{ACKNOWLEDGEMENTS}

This work was made possible with the support of the following institutions/people: The National Research Foundation, which provided funding for Tshwane University of Technology projects on neutralisation and sulphate removal through their Technology and Human Resources for Industry Programme (THRIP); Rand Water, which funds activities falling under the Rand Water Chair in Water Utilisation at the Tshwane University of Technology, and Tshwane University of Technology, which provided substantial financial support for the Research Programme. Thanks to Prof. Fritz Carlsson for editing the manuscript.

\section{REFERENCES}

APHA, AWWA and WEF (1985) Standard Methods for the Examination of Water and Wastewater (12 ${ }^{\text {th }}$ edn.). American Public Health Associaton, New York.

AUBÉ B (2004) The science of treating acid mine drainage and smelter effluents. URL: http://www.infomine.com/publications/does/Aube. pdf (Accessed 16 March 2007).

CREAMER T (2012) TCTA again warns of funding shortfall for acid water projects. Mining Weekly, 19 January 2012.

EXPERT TEAM OF THE INTER-MINISTERIAL COMMITTEE UNDER THE COORDINATION OF THE COUNCIL FOR GEOSCIENCE (2010) Mine water management in the Witwatersrand Goldfields with special emphasis on acid mine drainage. Report to the Inter-Ministerial Committee on Acid Mine Drainage, 21 October 2012.

MAREE JP (2012) Mine water - Pump or decant? Internal report, Tshwane University of Technology.

MAREE JP, DE BEER M, STRYDOM WF, CHRISTIE ADM and WAANDERS FB (2004) Neutralizing coal mine effluent with limestone to decrease metals and sulphate concentrations. Mine Water Environ. 23 (2) 81-86.

OSUCHOWSKI R (1992) Advanced treatment of acid mine water. Technology SA April 1992 9-11.

RUTO S, MAREE JP, ZVINOWANDA CM, LOUW WJ and KOLESNIKOV AV (2011) Thermal studies on gypsum in a pilot-scale, rotary kiln. Proc. Water in the South African Minerals Industry, Southern African Institute of Mining and Metallurgy, 15-17 February 2011, White River.

STUMM W and LEE GF (1961) Oxygenation of ferrous iron. Ind. Eng Chem. 53 (2) 143-146.

VAN NIEKERK A (2011) Personal communication, 5 July 2011. Dr André van Niekerk, Divisional Director - Water Engineering, Golder Associates Africa (Pty) Ltd, PO Box 13776, Hatfield, 0028, South Africa.

VOGEL AI (1989) Textbook of Quantitative Inorganic Analysis (5 ${ }^{\text {th }}$ edn.). John Wiley and Sons, New York. 368 pp.

ZINCK J (2006) Disposal, reprocessing and reuse options for acid drainage treatment sludge. In: Barnhisel RI (ed.) 7th International Conference on Acid Rock Drainage (ICARD), 26-30 March 2006, St. Louis MO. American Society of Mining and Reclamation (ASMR), Lexington. 